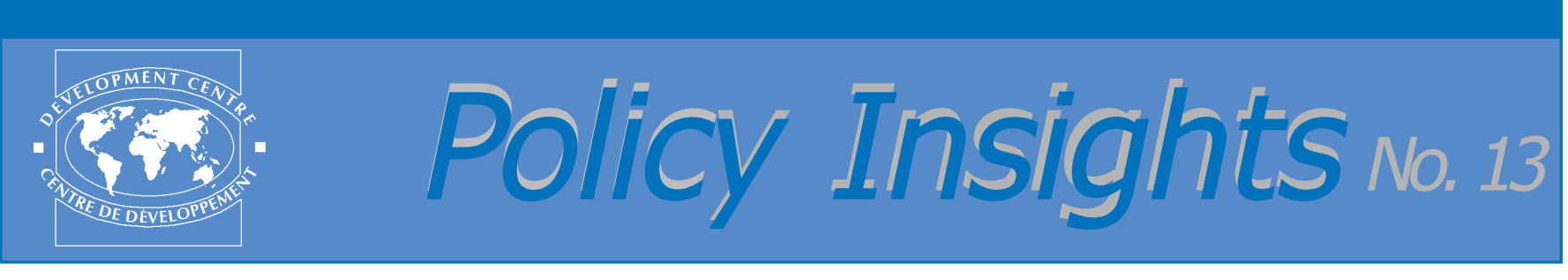

\title{
MDGs, Taxpayers and Aid Effectiveness
}

\author{
by Ida Mc Donnell and Henri-Bernard Solignac Lecomte ${ }^{1}$
}

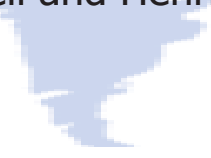

MDGs and new aid-effectiveness targets are an opportunity for donors to explain what they do before growing scepticism erodes taxpayer support for aid.

If political leaders from donor countries attending the September 2005 UN Summit on Millennium Development Goals (MDGs) are genuinely committed to poverty reduction and long-term development, it is in their interest to shift from dependency on passive, uninformed public support for aid to a more critically aware constituency at home.

One might argue that commitments to increase official development assistance (ODA) have been un-contentious precisely because of mistaken public perceptions about development aid: people see it as an expression of sympathy and solidarity with victims of humanitarian crises, whereas aid professionals actually support longer-term, less mediafriendly development schemes in poor countries. Banking on the status quo may, however, be a dangerous strategy. Persistent budget deficits and weak economic performance in OECD countries create a risky climate for ODA increases, especially once the debt-relief "bubble" is over. Backed by OECD taxpayers' vulnerable support for aid, ODA is often among the first budgets to be cut in difficult times.

Greater public awareness and concern about development issues could put MDG-related issues on domestic political agendas and thereby protect ODA commitments. Creating that awareness will mean engaging people in a deeper debate about development, and thus building a "real" constituency. This is both a risk and an opportunity for policy makers: while public scrutiny would put new pressure on them to show that development co-operation policies work, it might just provide the stimulus required to improve their effectiveness and achieve the MDGs. Public awareness raising is thus a key growth area in the global debate on the MDGs.

\section{Who knows about the MDGs?}

Five years after the Millennium Summit, the Goals and the issues they address are still far from the electoral agenda in donor countries. Firstly, as shown by the latest public opinion surveys in the EU, Canada, and the United States, only a minority -12 per cent on average - of OECD citizens have actually heard of the MDGs (Eurobarometer, 2005; Focus Canada, 2004; see the full list of poll sources at the end of this document). "Real" awareness may be even lower: in Canada, for example, 62 per cent of those who had heard of the Goals (13 per cent of respondents) could not say what they were about. Of course, MDG awareness should not be confused with public engagement and consciousness of global poverty. While percentages of those who admit to knowing about the MDGs may be below or close-to-average (e.g. 8 and 13 per cent in the United Kingdom and the Netherlands respectively) ${ }^{2}$, this may be because advocacy campaigns have highlighted awareness of the issues, rather than the MDGs themselves (Box 1).

Secondly, although the MDGs present aid to the public as only one of the ways to reduce poverty (together with trade, debt forgiveness, etc.), OECD citizens' awareness of development remains overwhelmingly limited to aid, which an average of 80 per cent of them have supported for several decades, but which they perceive as charity, provided on humanitarian grounds (Mc Donnell et al. 2003; Eurobarometer, ibid.; Synovate, 2005). Only a 


\section{Box 1. United Kingdom, 2005: a Peak in Public Mobilisation against World Poverty}

The Make Poverty History campaign, which calls for trade justice, debt cancellation and more and better aid for the world's poorest countries, has been instrumental in stimulating a significant mobilisation and public debate about the Goals. Almost 250000 people demonstrated in Edinburgh during the G8 Summit on 2 July (www. makepovertyhistory.org/).

minority - usually better-educated, young, urban-dwelling cosmopolitans - are actually knowledgeable and involved. Even where increasing awareness of debt and trade issues can be observed among the "passive engaged", most people do not understand the issues, and are wary and cynical of them (Synovate, ibid.).
Mixed feelings about reaching the MDGs by 2015

Halving global poverty by 2015 is considered in OECD countries as the least achievable MDG (Figure 1). Only 29 per cent of Europeans and 31 per cent of Canadians think that a reduction in extreme poverty and hunger will be achieved by 2015 (Eurobarometer, idem; Focus Canada, 2004). In 2002, only 16 per cent of opinion leaders in industrial countries thought that it was "very likely" or "somewhat likely" that poverty will be reduced by half by 2015 (World Bank, 2003). Yet, owing to the economic performance of China and India alone this Goal is highly likely to be reached at the global level.

This negativity probably stems from the perceived difficulty of the problem compared to other Goals. Results from the Canadian poll suggest this: lack of money or resources (18 per cent), lack of will (18 per cent), and the enormity of the task at hand (14 per cent) were the most frequently cited obstacles to achieving the Goals.

Figure 1. MDGs to be definitely/probably achieved by 2015

(European Union member states, December 2004)

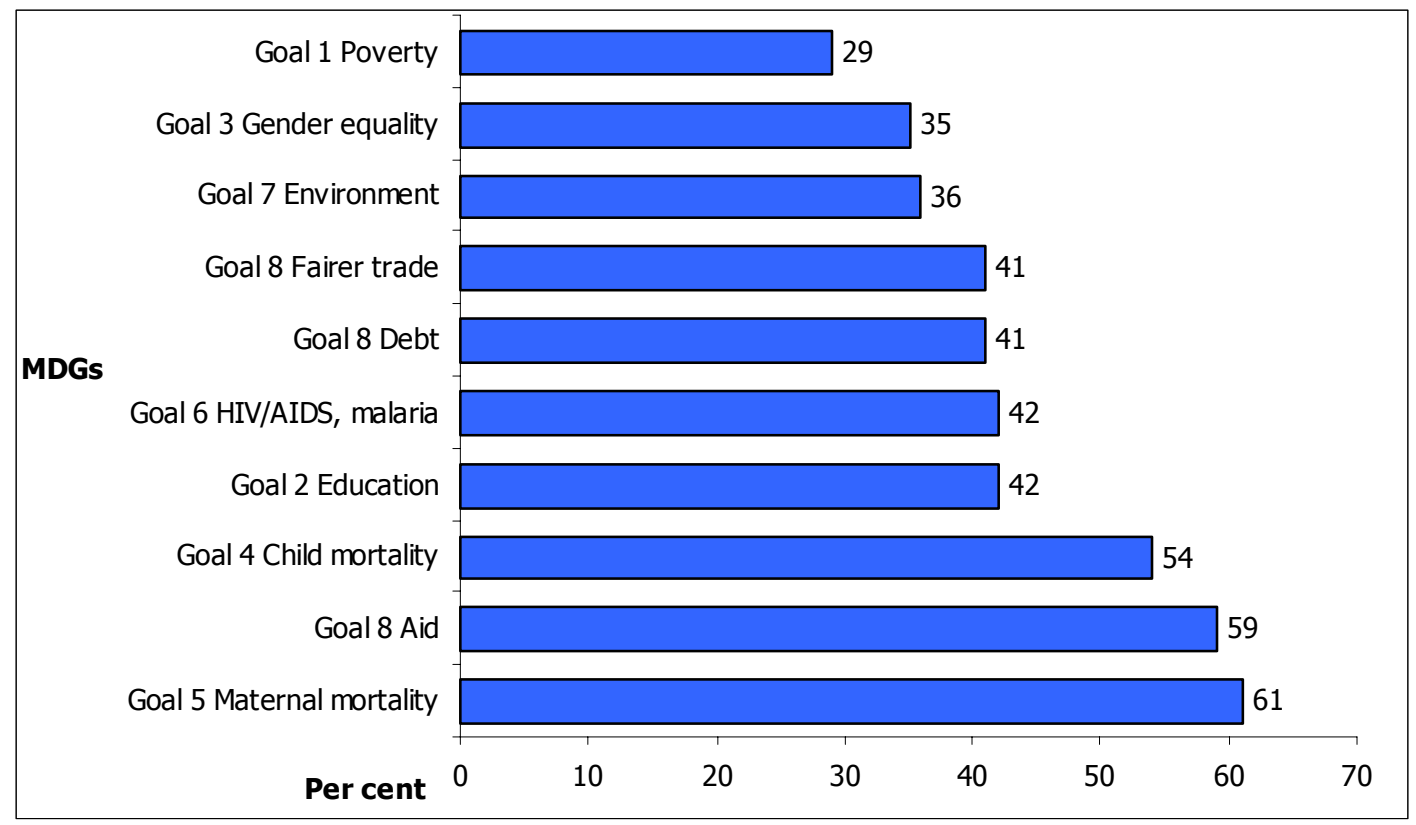

Source: Special Eurobarometer wave 62.2 TNS Opinion \& Social, Attitudes towards Development Aid, 2005, Brussels. 
Optimism for reducing maternal and child mortality is greater and may be motivated by emotion, reflecting respondents' hopes rather than a judgement of how likely it is that they will be achieved, as public opinion is often more sensitive to issues affecting women and children (hence the use of such imagery in NGO fundraising, media coverage of famines, conflicts, etc.).

OECD citizens are confident that national pledges to increase development aid to countries committed to reducing poverty will be honoured. This suggests that they do not have to be convinced about the need for more aid, though the way the question was phrased - linking aid to "good countries" - might have influenced their response. It may also stem from people's perception that they can participate in the delivery of aid: indirectly through tax and directly by contributing to NGOs. The same does not apply to the more complex issues of trade and debt relief. People seem convinced that aid is important in spite of their doubts about its effectiveness.
What people think OECD governments should do to achieve the MDGs

When asked what their governments should do, respondents in the Eurobarometer and Focus Canada polls were offered a choice of actions covering most of the targets for Goals seven and eight ${ }^{3}$. Their answers (Figure 2) provide a useful indication on what should be communicated about their government's actions and achievements against world poverty. For instance, conflict is perceived as an over-riding constraint to attaining the MDGs. Citizens will thus want to know what their government is doing to prevent arms sales to poor, badly governed countries. Polls also demonstrate that fairer trade treatment for developing countries is politically feasible in OECD-member countries, particularly in Canada, where it is considered to be even more important than increased aid. Yet the EU's Everything But Arms initiative - granting free access to imports other than arms and munitions from least developed countries - has been promoted from Brussels by the European Commission, but hardly at all by national political figures in member countries.

Figure 2. Most Important Actions for OECD Governments to Achieve the MDGs

(European Union member states and Canada, 2004)

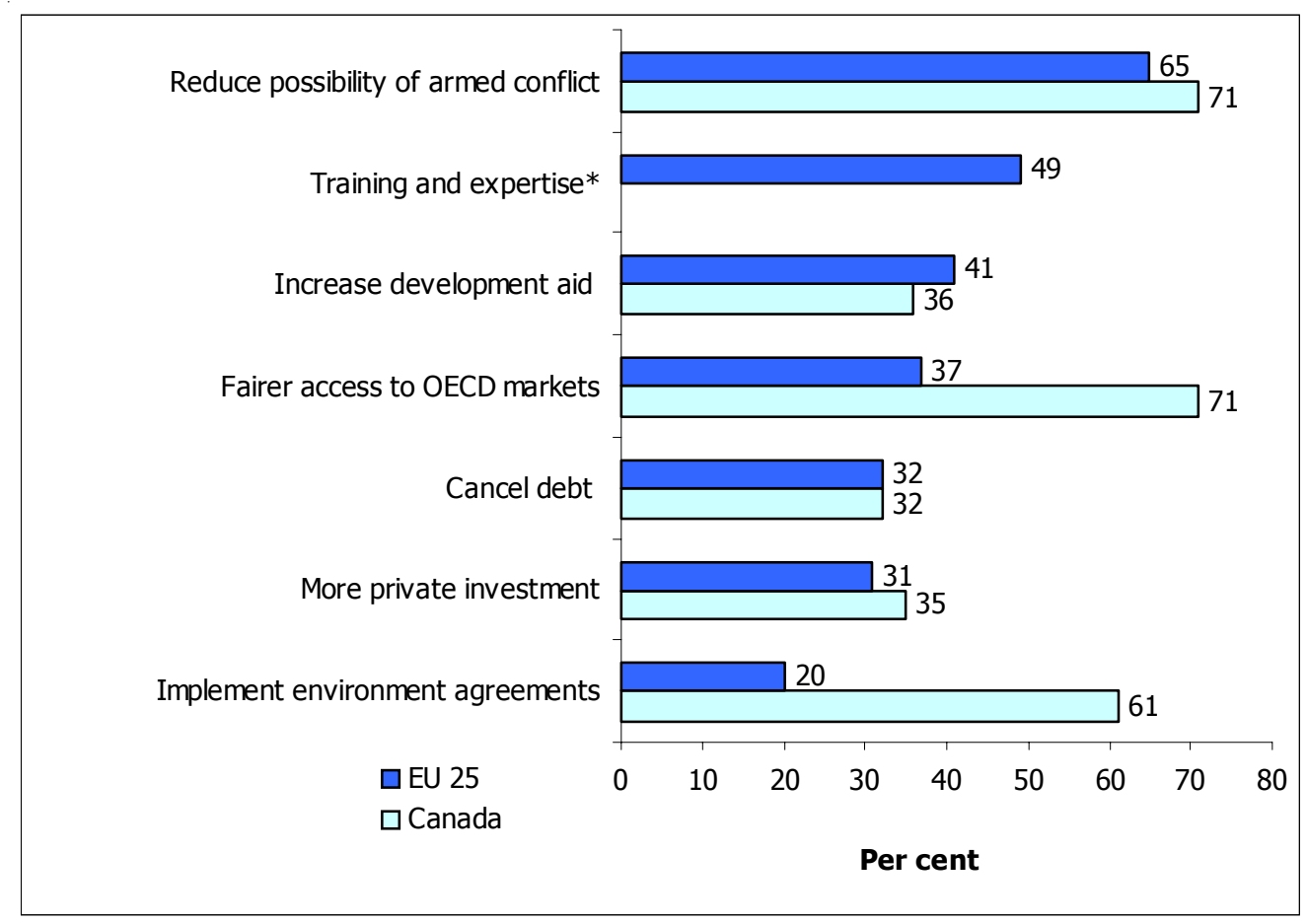

* = not available for Canada

Source: Special Eurobarometer Wave 62.2 TNS Opinion \& Social, 2005, Attitudes towards Development Aid, Brussels; Focus Canada, Environics Research Group, 2004, Canadian Attitudes towards Development Assistance, Canada. 
Building a public constituency for the MDGs requires longterm, sustainable strategies for awareness raising that can compete within the information society. Yet this has been problematic because public engagement and education have not been priorities in national development cooperation policies. Current levels of expenditure in most OECD countries on public awareness raising on development issues are inadequate (Table 1). The overall annual DAC members' budget for public information, communications and development education is approximately $€ 200$ million or 0.26 per cent of total ODA. The Netherlands spends almost $€ 4$ per person under this heading, Norway $€ 2.50$, Sweden $€ 2.29$ and Belgium $€ 2$, compared with $€ 0.04$ in Japan, $€ 0.08$ in Australia, and $€ 0.12$ in Germany. In May 2005, a European Conference proposed 3 per cent of ODA as a minimum target for public awareness raising and development education expenditure ${ }^{4}$.
Scepticism about aid effectiveness is widespread among aid supporters, many of whom question whether it actually reaches the poor people to whom it is destined, blaming corrupt governments in developing countries and aid mismanagement by both donors and recipients (see Box 2). This presents a major challenge for communicators and development educators, but the belief that aid should be increased (Figure 2 above) indicates that such scepticism may be alleviated if it can be tackled upfront. Commitment to poverty reduction by developing-country governments could be measured by efforts to diminish corruption and aid diversion, implement poverty-reduction strategies, and promote political reform. The results of such efforts must be publicised: it is aid effectiveness, not promises of higher aid volumes that people want to hear about.

Table 1. OECD/DAC Donors Expenditure on Information and Development Education

\begin{tabular}{llccccc}
\hline Country / donor & Year & $\begin{array}{c}\text { Public information } \\
\text { (communication } \\
(€ \text { million })\end{array}$ & $\begin{array}{c}\text { Development } \\
\text { education } \\
(€ \text { million })\end{array}$ & $\begin{array}{c}\text { Total } \\
\text { spending } \\
(€ \text { million })\end{array}$ & $\begin{array}{c}\text { Share of } \\
\text { total ODA } \\
(\%)\end{array}$ & $\begin{array}{c}\text { Expenditure } \\
\text { per capita } \\
(€)\end{array}$ \\
\hline Australia & $2004 / 05$ & 1.28 & 0.45 & 1.74 & 0.15 & 0.08 \\
Austria & 2004 & 1.38 & 4 & 5.38 & 0.96 & 0.67 \\
Belgium & 2003 & 21 & n.a.* & 21 & 1.79 & 2.02 \\
Canada & 2004 & 8.6 & 3.8 & 12.4 & 0.60 & 0.38 \\
Denmark & 2004 & 1.48 & 7.09 & 8.57 & 0.52 & 1.59 \\
European Commission (DG DEV) & 2004 & 3.04 & 0.16 & 3.2 & n.a. & n.a. \\
Finland & 2004 & 1.45 & 1.62 & 3.07 & 0.58 & 0.59 \\
France a) & 2004 & 2 & 2.6 & 4.6 & 0.07 & 0.08 \\
Germany & 2004 & 1 & 10 & 10 & 0.18 & 0.12 \\
Greece & 2004 & n.a. & n.a. & n.a. & n.a. & n.a. \\
Ireland & 2004 & 0.85 & 2.9 & 3.75 & 0.79 & 0.94 \\
Italy & 2004 & n.a. & n.a. & n.a. & n.a. & n.a. \\
Japan & 2004 & 6.1 & 0.18 & 6.28 & 0.09 & 0.04 \\
Luxembourg & 2004 & 0.24 & 0.96 & 1.2 & 0.62 & 2.5 \\
Netherlands & 2004 & 4 & 60 & 64 & 1.86 & 3.96 \\
New Zealand & 2004 & n.a. & n.a. & n.a. & n.a. & n.a. \\
Norway b) & 2005 & 11.6 & n.a.* & 11.6 & 0.65 & 2.56 \\
Portugal & 2004 & 0.25 & 0.25 & 0.25 & 0.03 & 0.006 \\
Spain c) & 2003 & n.a. & 3.18 & 3.18 & 0.15 & 0.08 \\
Sweden & 2005 & 7.58 & 13 & 20.58 & 0.94 & 2.29 \\
Switzerland & 2004 & 5.85 & 1.94 & 7.79 & 0.70 & 1.05 \\
United Kingdom & $2004 / 05$ & 2.98 & 9.01 & 12 & 0.19 & 0.2 \\
United States & 2005 & 2.48 & n.a. & 2.48 & 0.02 & 0.008 \\
\hline & & $\mathbf{8 3 . 1 6}$ & $\mathbf{1 2 0 . 7 1}$ & $\mathbf{2 0 3 . 8 7}$ & $\mathbf{0 . 2 6}$ & \\
\hline
\end{tabular}

Notes: * Development education budget could not be disaggregated from overall Public information and communications budget. a) Includes budget for Ministry of Foreign Affairs (DGCID) and the Agence Française de Développement.

b) Budget of Ministry of Foreign Affairs only.

c) Rough estimation for expenditure in Spain from data reported to DAC under Code: 99820: "Promotion of development awareness".

Sources: Questionnaire circulated at 2005 annual meeting of DAC Heads of Information and Communication. Supplementary data received from officials in development agencies/ministries. ODA figures: Preliminary Data for 2004, OECD DAC Statistics, available at www.oecd.org/dataoecd/59/51/34700392.pdf 


\section{Box 2. Public Opinion About Aid Effectiveness}

- 51 per cent of Europeans think that the aid provided by their government is making a difference to improving the lives of poor people in developing countries (Eurobarometer, idem).

- On average, 17 per cent say they did not know if aid was making a difference, a figure that reaches 34 per cent in Portugal, 24 per cent in Italy, 23 per cent in Ireland and 22 per cent in Spain (ibid.).

- 58 per cent of opinion leaders in industrial countries "strongly agree and somewhat agree" that foreign assistance is wasted due to corruption (World Bank, 2003).

- In Denmark, 52 per cent of respondents think that the bulk of development assistance is spent on administration and does not benefit the poor, while 49 per cent believe it disappears into the wrong pockets (Danish Ministry of Foreign Affairs, 2004).

- More than half those questioned in Japan do not approve of the quality of aid (JICA, 2001).

- Eight in ten (82 per cent) Canadians agree that much of the aid given to poor countries never gets to the people who need it most. 45 per cent mention corruption or corrupt governments and politicians in developing countries as the reasons aid never gets to the people who need it most (Focus Canada, Environics Research Group, 2004).

- In 2001, 57 per cent of Norwegians thought that emergency aid was successful, and 40 per cent believed that long-term assistance worked well. 67 per cent said that respect for human rights should be a condition for receiving aid (Statistics Norway, 2002).

\section{Moving forward}

The need for new approaches to communicating development realities and complexities is thus apparent. In order to devise them, co-operation is improving amongst donor agencies and between them and NGOs (Box 3). To mobilise citizens in support of the MDGs, communicators and development educators must find new ways to demonstrate that donors and recipients are actually working towards them as part of a shared global effort to reduce poverty. The MDGs could be used as yardsticks to showcase what has been achieved by developing-country governments and donors, thanks to more and better aid, fairer trade, debt relief and good governance. In turn, enhancing accountability at home would complement donor agencies efforts spelt out in the Paris Declaration (2005) to improve aid effectiveness.

\section{Box 3. Strengthening Public Awareness Raising in OECD Countries}

- The informal network of DAC Heads of Information and Communication is co-ordinating efforts to make communications for development a priority in OECD countries, working together to strengthen knowledge bases and share best practices on effective communications. Current activities focus on evaluation and the communication challenges in supporting the Paris Declaration on aid effectiveness: www.oecd.org/dev/opinion

- The UN Millennium Campaign is operating at both the national and international levels to inspire a global movement to achieve the Goals and eradicate extreme poverty by 2015: www.millenniumcampaign.org/

- The Global Education Network Europe project co-ordinated by the North-South Centre of the Council of Europe conducts peer reviews of global education in European countries: www.coe.int/T/E/NorthSouth_Centre/.

- European NGOs are working together and raising standards through CONCORD's Development Education Forum and the Development Education in Europe Project (DEEEP): www.deeep.org/

- The Global Call to Action against Poverty is a worldwide alliance committed to making world leaders live up to their promises, and to making a breakthrough on poverty in 2005: www.whiteband.org/ 


\section{Notes}

1. Sincere thanks to Colm Foy and Felix Zimmermann.

2. A national opinion poll commissioned in $\mathbf{2 0 0 5}$ by the Dutch National Commission for International Co-operation and Sustainable Development (NCDO) came up with slightly different results to Eurobarometer, where 20 per cent say they have heard of the MDGs (see presentation by S. Penseel, NCDO at www.oecd.org/dev/meetings/HOI2005).

3. As for Americans asked which Goal they supported the most, they ranked universal access to primary education first (23 per cent) followed by HIV/AIDs/malaria (20 per cent) and access to safe drinking water (16 per cent). (POS with Talmey \& Drake Research Strategies Inc., 2004).

4. "National and European authorities should ensure there is adequate funding for development education and awareness raising in their planning. It is proposed that the European Commission and Member states move towards or beyond a figure of 3 per cent of ODA, as proposed in a UNDP Report. This increase in funding implies the necessary quality, efficiency and effectiveness of development education and awareness raising activities.", conclusion B-5 of the European Conference on Public Awareness and Development Education for NorthSouth Solidarity, organised by the Directorate-General of Belgian Development Co-operation and the European Commission with the NorthSouth Centre of the Council of Europe, the OECD Development Centre and CONCORD. (www.euforic.org/awareness-sensibilisation).

\section{Bibliography}

Focus Canada, Environics Research Group (2004), Canadian Attitudes toward Development Assistance, Ottawa.

HCCI (2004), Sensibilisation du public aux questions de coopération et de solidarité internationale : le volet «collectivités locales », Haut Conseil de la Co-opération Internationale, Paris.

JICA (2001), "JICA ni kansura zenkoku simin anke-to chosa houkokusho", March.

Mc Donnell, I., H.-B. Solignac Lecomte and L. Wegimont (2003) (eds.), Public Opinion and the Fight against Poverty, Development Centre Study, with the North-South Centre of the Council of Europe, OECD, Paris.

Paris Declaration on Aid Effectiveness: www.aidharmonization.org/

Public Opinion Strategies (POS) with Talmey \& Drake Research Strategies Inc. (2004), MDG Campaign Research: A Survey of 1,000 Registered Voters Conducted April 13-18, on behalf of the Better World Campaign, Washington, D.C.

Rønning, E. (2000), Holdninger til og kunnskap om norsk utviklingshjelp 1999, Oslo.

Special Eurobarometer 222 Wave 62.2 TNS Opinion \& Social (2005), Attitudes towards Development Aid, Eurobarometer, Brussels. http://europa.eu.int/comm/public_opinion/archives/ebs/ebs_222_en.pdf

Statistics Norway (2002), Attitudes towards Norwegian Development Aid in 2001: Persistent approval of development aid, Oslo: www.ssb.no/uhjelphold_en/

Synovate Research Invented (2005), Public Perceptions of Poverty, Qualitative Research Findings: Wave 1, UK, not published.

The Danish Population's Perception and Knowledge of Development Assistance Issues (2004), communiqué received from Danish Ministry of Foreign Affairs, not published.

World Bank (2003), The Global Poll Multinational Survey of Opinion Leaders 2002, Princeton Survey Research Associates for the World Bank, Washington, D.C. 


\section{OECD Development Centre Policy Insights}

No. 12 The International Aid System: A Question of Perspective by Felix Zimmermann

No. 11 Private Health Insurance for the Poor in Developing Countries by Denis Drechsler and Johannes Jütting

No. 10 The Human Dynamics of Aid by Malcolm MacLachlan and Stuart C. Carr

No. 9 Adaptive Capacity and Inclusive Development: by Ulrich Hiemenz

No. 8 Energy and Poverty in Africa by Céline Kauffmann

No. 7 Financing SMEs in Africa by Céline Kauffmann

No. 6 African Economic Performance in 2004: A Promise of Things to Come? by Nicolas Pinaud and Lucia Wegner

No. 5 Decentralisation and Poverty Reduction by Johannes Jütting, Elena Corsi and Albrecht Stockmayer

No. 4 Policy Coherence of OECD Countries Matters: Evidence from East Asia by Kiichiro Fukasaku and Alexandra Trzeciak-Duval

No. 3 Corporate Governance: A Development Challenge by Charles Oman and Daniel Blume

No. 2 Mobilising Public Opinion against Global Poverty by Jude Fransman and Henri-Bernard Solignac Lecomte

No. 1 Towards an East Asia Free Trade Area by Shujiro Urata 
Development Centre Policy Insights

www.oecd.org/dev/insights

Development Centre Policy Briefs www.oecd.org/dev/briefs

Development Centre Working Papers

www.oecd.org/dev/wp

\section{OECD $\ll$}

Readers are encouraged to quote or reproduce material from OECD Development Centre Policy Insights for their own publications. In return, the Development Centre requests due acknowledgement and a copy of the publication. Full text of Policy Insights and more information on the Centre and its work are available on its web site:
OECD Development Centre 2, rue André-Pascal, 75775 Paris Cedex 16, France Tel.: +33-(0)1 45.24.82.00 Fax: +33-(0)144306149

E-mail: dev.contact@oecd.org 